IZA DP No. 4479

Eliciting Individual Preferences for Pension Reform

Yosr Abid Fourati

Cathal O’Donoghue

October 2009 


\title{
Eliciting Individual Preferences for Pension Reform
}

\author{
Yosr Abid Fourati \\ National University of Ireland, Galway \\ Cathal O'Donoghue \\ National University of Ireland, Galway \\ and IZA
}

\section{Discussion Paper No. 4479 \\ October 2009}

IZA
P.O. Box 7240
53072 Bonn
Germany

\author{
Phone: +49-228-3894-0 \\ Fax: +49-228-3894-180 \\ E-mail: iza@iza.org
}

\begin{abstract}
Any opinions expressed here are those of the author(s) and not those of IZA. Research published in this series may include views on policy, but the institute itself takes no institutional policy positions.

The Institute for the Study of Labor (IZA) in Bonn is a local and virtual international research center and a place of communication between science, politics and business. IZA is an independent nonprofit organization supported by Deutsche Post Foundation. The center is associated with the University of Bonn and offers a stimulating research environment through its international network, workshops and conferences, data service, project support, research visits and doctoral program. IZA engages in (i) original and internationally competitive research in all fields of labor economics, (ii) development of policy concepts, and (iii) dissemination of research results and concepts to the interested public.
\end{abstract}

IZA Discussion Papers often represent preliminary work and are circulated to encourage discussion. Citation of such a paper should account for its provisional character. A revised version may be available directly from the author. 
IZA Discussion Paper No. 4479

October 2009

\section{ABSTRACT \\ Eliciting Individual Preferences for Pension Reform}

Pension systems have recently been under scrutiny because of the expected population ageing threatening its sustainability. This paper's contribution to the debate is from a political economic perspective as it uses data from a choice experiment to investigate individual preferences for an alternative state pension scheme based around preferences for cost, poverty, retirement age and pension parameters. Answers are used to estimate a lifecycle utility model of preferences towards pensions' parameters. Results suggest that individuals' value orientation is an important determinant of their preferences. Respondents' income determines which degree of redistribution is preferred. However, preferences according to age are in contradiction with what is suggested in theory.

JEL Classification: $\quad \mathrm{HO}, \mathrm{I3}$

Keywords: population ageing, pension system reform, redistribution, stated preferences

Corresponding author:

Yosr Abid Fourati

Department of Economics

National University of Ireland, Galway

University Road

Galway

Ireland

E-mail: y.abid1@nuigalway.ie

\footnotetext{
* The authors gratefully acknowledge financial assistance from the Department of Economics of the
} National University of Ireland (NUI), Galway. 


\section{Introduction}

The implementation of pension systems has been one of the most important achievements in terms of social policy in the developed world during the twentieth century. However, discussions on the "pension crisis" and the way to reform pension systems have rapidly emerged due to demographic and budgetary pressures. Pension reform is nowadays in the forefront of the political agenda of many European countries. Still, the reform process is slow, despite the urgency required, partially due to political sensitivity. This is partially and importantly due to the fact that public pension's schemes are redistributive.

The main focus of this paper is to answer the following questions: what are individual preferences over redistribution by state pension systems and what determines these preferences? Several studies within the political economy theory field have attempted to identify the forces that drive the support for income redistribution and the welfare state. Schwarze and Härpfer (2007) summarize these hypotheses into three arguments. The first is an efficiency argument which posits that individuals are willing to pay to reduce the risk associated with their ex ante income distribution because they may be risk averse. The second is the self-interest argument which considers that egoistic pecuniary motives are a major determinant of individual preferences. The third argument relates to inequality aversion. The logic, according to which people would support redistributive government policies if they expect to gain from these policies, has been suggested by the median voter model (Meltzer and Richard (1981)) ${ }^{2}$, as well as by the Esping-Andersen (1985) as the power resource theory. However, both on the theoretical and empirical grounds, the median voter hypothesis has often been questioned (Moene and Wallerstein (2003), Kenworthy and McCall (2008)). Indeed, preferences may include the social status enjoyed by the individual. Individuals may also be inequality averse. Recently, stated preferences techniques have been introduced to analyze preferences for redistribution by the state. For instance, Corneo and Grüner (2002) find empirical evidence that three effects drive support for redistributive policies: the "homo-oeconomicus" effect, the "public values effect" and the "social rivalry effect". On the contrary, Fong (2001) finds little evidence that self interest is an important determinant of demand for redistribution, in his study social preferences are more important.

In the field of distributive preferences for pension programs, it has been shown that social security is supported primarily by self-interested desires on the part of an important proportion of citizens. Old age public pensions create self-interested beneficiaries that might be against the retrenchment of the welfare state (See Pierson, "Dismantling the Welfare State" (1994)). Little empirical studies have conducted to confirm or disconfirm this hypothesis (apart from Lynch (2006)). However, preferences may also be otherregarding, referred to as social preferences. For example, means-tested schemes have proved to be politically sustainable even if they are concentrated on a small range of people. On the empirical side, a strand of the literature has developed recently to analyze the preferences and opinion of citizens concerning pensions. See for instance the Special Eurobarometer survey on Pension Policy and Pension Reform conducted in 2004. Boeri et al. (2001) use stated preferences contingent valuation methods to analyze attitudes

${ }^{2}$ Meltzer and Richard (1981) and Iverson (2005) posit that self-interest is a key determinant of attitudes towards redistributive social policies. 
towards possible pension reforms in Germany, Italy, France and Spain. van Groezen et al. (2008) analyze the determinants of people's preferences for particular kinds of pension provision (public, occupational and private) in 15 European countries. Delaney et al. (2006), examine preferences for specific forms of redistribution in Ireland: unemployment payments, old age pensions and child benefit and find support to the selfinterested preferences. See also Ferrara (1993); Lynch (2006); van Els et al. (2003); Devroye (2003), Hamil-Luker (2001). In this study we will utilize a preference survey undertaken in Ireland to try to answer these questions.

Old age pensions are central for the Welfare State in Ireland. On the one hand, they fulfil various objectives among which redistribution and poverty alleviation. On the other hand, public pension expenditures represent a large share of social public expenditures. Over the last decade, several reports (especially governmental) and academic research papers aiming at presenting an overview of the Irish pension system and possible alternatives as regard policy options for reform have been published. Recent examples are the two reports prepared under the aegis of the Pensions Board: the "National Pensions Review (2005)" and "Special Savings for Retirement (2006)"; and the "Green Paper on Pensions (2007)". Even though these reports have covered a wide range of issues, people's opinion and choices regarding the future of the pension system have rarely been taken into consideration.

The remainder of this paper is structured as follows. Section two describes the functioning of the Irish pension system, the challenges that threaten its sustainability and the debate around pension reform in Ireland. Section three introduces a life cycle utility model for pension preferences. Section four presents the theoretical basis of discrete choice experiments. Section five outlines the preparation of the questionnaire and presents summary statistics for the sample. In section six, we present results from different discrete choice models. Finally, in section seven, we discuss future directions of research.

\section{The challenges of population ageing and poverty for the Irish pension system}

\subsection{Pension provision in Ireland}

The Irish pension system is in many respects typical of the Anglo-Liberal style of welfare state, with a relatively insignificant social insurance system, where means testing and progressive income taxes are more important. The state pension system has its origins in the UK old age assistance act of 1908, with a social insurance pension being introduced for those $70+$ in 1961, with a retirement pension at 65 introduced in 1970 (See O'Donoghue (2002). The scheme is Beveridgean in focus with more emphasis on poverty alleviation than on income replacement. Together, the public and private pension schemes operating in Ireland (Figure 1) serve several objectives in different degrees, namely, maintenance of individual standard of living during the period of retirement, poverty alleviation and income redistribution. 


\section{Figure 1}

Pillars of the Irish pension system
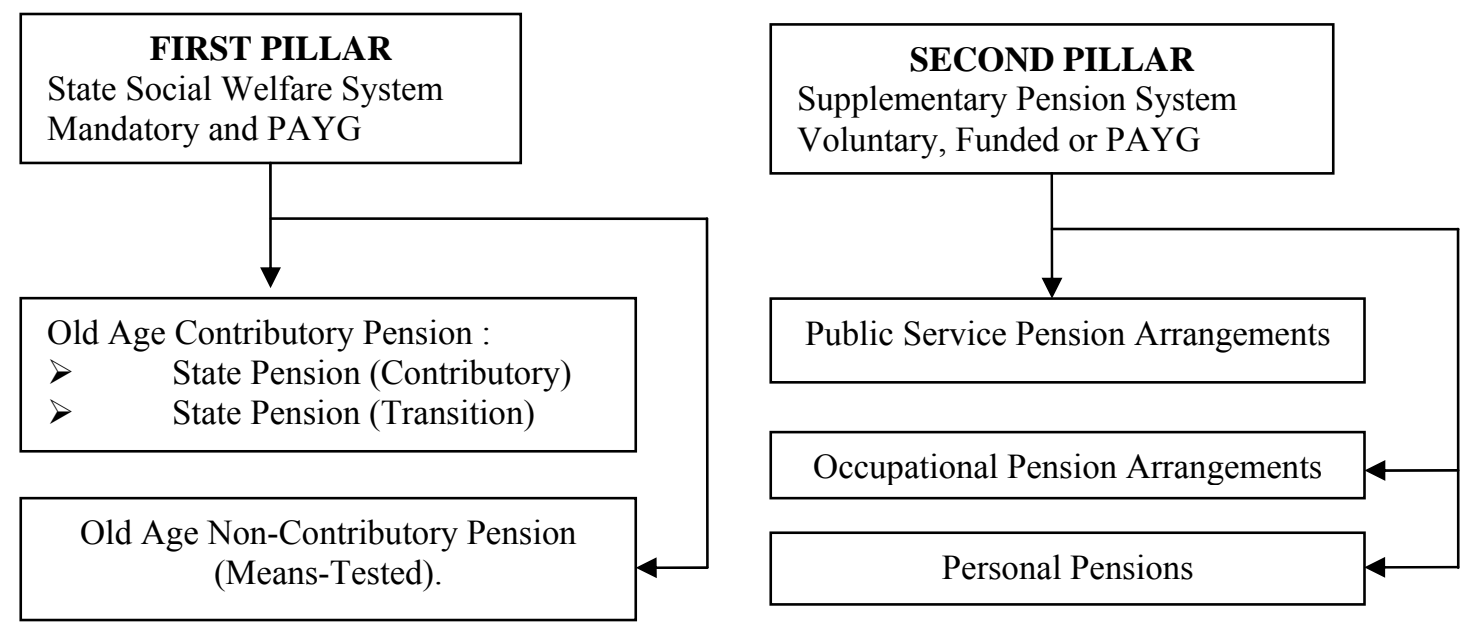

\subsection{The old age social welfare system}

The public pension system - first pillar, public and mandatory - is funded on a Pay As You Go (PAYG) basis has three components a State pension - Contributory - available from age 66; a State pension - Transition, available from age 65, but requiring retirement; and, a survivor's pension. All are flat rate payments that vary slightly based upon contribution history but independent of earnings, with additional payments for dependants. These are supplemented by means-tested benefits, financed through taxation for those not covered by the insurance system, resulting from significant historical gaps in social insurance coverage. These are nevertheless declining due to the progressive extension of coverage since 1974, resulting in the share of pensioners claiming meanstested payments falling from $45 \%$ in 1994 to $30 \%$ in 2004, and expected to reach $14 \%$ in 2017. The current replacement rate for a single pensioner is AAA.

\subsection{The supplementary pension scheme}

The second and third (private and voluntary) pillars are represented by supplementary occupational and/or individual pensions: voluntary tax incentivised private or occupational system, which main objective is to smooth income over an individual's lifetime. Growth in occupational and private pension schemes only accelerated in earnest after the Finance Act 1972 which set up a clear legal and fiscal framework for them, but has levelled out in recent years. After a period of increasing coverage of occupational pensions, ESRI surveys in 1995 found that $52 \%$ of the employed workforce was covered by occupational schemes, down from $54.4 \% 1985$, but up from $35.6 \%$ in 1974 . Recent Statistical Office figures in 2008 indicate that the percentage of employees with an occupation pension has remained relatively constant fallen to about $52 \%$. The proportion of defined contribution schemes has increased from 12\% in 1992 (National Pensions Board (1993)) to 17\% in 1995 (Hughes and Whelan (1996)) to 33\% in 2008 (National 
Pensions Board (2008)) of which the majority are in the private sector, where about $50 \%$ of the pension members are members of DC schemes.

Personal pension arrangements consist essentially of Retirement Annuity Contracts (RACs) used by the self-employed and more recently the Personal Retirement Saving Accounts (PRSAs) introduced in 2003 to meet the willingness of the government to extend the supplementary coverage. The main problem related to supplementary arrangements in Ireland concerns the low coverage (around $50 \%$ ), especially among self employed. Low contribution rates represent a further inefficiency; they are seen to be insufficient to guarantee adequate replacement rates after retirement. It is therefore not surprising that the government makes a priority of the necessity to increase incentives that would make employers, employees, self-employed and others contribute more into private pension arrangements (both occupational or private). The government is also reviewing its incentives policy to be more effective.

\subsection{Poverty among the elderly}

Pensioners in Ireland are a vulnerable group due to being highly dependent on transfers payments and having very low labour force participation. In this respect, the National Anti-Poverty Strategy (NAPS) adopted by the government in 1997 to address the problem of poverty, and National Action Plan against Poverty and Social Exclusion (NAP/incl), identify older people as a particularly vulnerable group to poverty, and both documents list a number of targets in relation to income support and service provision for the elderly. The average net income for a pensioner unit in 2005 was $€ 327.55$ per week (Green Paper (2007)). In 2002, a single pensioner had a replacement rate relative to Gross Average Industrial Earnings of $27.2 \%$ if reliant on means tested benefits and $32 \%$ of Gross Average Industrial Earnings. While coverage of the insurance scheme is increasing, the low replacement rate and lower indexation the level of household earnings growth over the boom years saw a rapid rise in elderly poverty; the relative poverty rate of pensioners rose from $5.9 \%$ in 1994, to $43.3 \%$ in 2000 compared with $16.9 \%$ for the working age population (DSFA (2002)) and $44.1 \%$ in 2001. Increased indexation of state pensions in the past decade has seen a fall in the poverty rate to $14 \%$ in 2006, but rose again in 2007 to $17 \%$.This is high by international standards. In 2005 , Ireland had the highest level of relative income poverty in the EU among over-65s (OECD (2005)).

\subsection{Population ageing: Key demographic trends}

While less serious than some other EU countries, nevertheless, demographic ageing expected to result in increasing the old age dependency ratios, which will put fiscal pressures on the public finances. Nevertheless, the demographic situation is relatively favourable for the next 20 years (Gerald (2004)), especially compared to the situation in the other European countries. Ireland still has a young population, and consequently a longer period to prepare for the transition from low to high dependency. In the OECD countries for instance, the old age dependency ratio is expected to double by 2050 , to around 40 percent compared to an average 18 per cent in the 1990s (OECD Social Policy Studies (1996)), whereas in Ireland, it will be rising from 15 percent to 36 percent (Department of Social and Family Affairs (2006))

The increase of the population share of those aged 65 and over represents the main pressure on the public services as age-related public expenditures will have to rise. 
Pensions are expected to represent the most important part of these increases. Hence, much of the debate relating to the pensions public policy in Ireland centres around the impact of demographic and economic change on the public finances (DOF (1998)) and the potential cost and funding arrangements. Public spending on first pillar pensions (including public service pensions) is projected to rise from $4.6 \%$ in 2000 to roughly 9$14 \%$ of GDP in 2050 (Natali (2004)). Thus the country is faced with both cost and adequacy issues in relation to the pensioner population. Consequently, the combination of the poverty risk among the elderly with the challenging demographic pressures calls for targeted intervention of the State in the field of pensions.

\subsection{Reforming the Irish pension system}

Because of the concerns raised above about the future increase in public pension expenditures, the National Pensions Reserve Fund Act 2000 established a national pensions fund to help finance both public pensions and public service occupational pensions. Each year, at least 1 per cent of GNP will be deposited in the fund between 2001 and 2055. From 2025 the exchequer will be able to draw down monies from the fund to finance expenditures on public pensions and on the occupational pensions of public sector workers.

There have been a number of structure reforms over the 1990's and 2000's that has resulted in an increase in coverage and since 2001 an increased replacement rate, towards a target of $34 \%$ of average earnings set by the National Pensions Policy Initiative $\left(\mathrm{NPPI}^{3}\right)$. The NPPI also advocated increasing supplementary pension coverage rates with a target coverage rate of $70 \%$ and through increasing personal pension accounts through setting legislative framework to put in place to provide Personal Retirement Saving Accounts (PRSAs); However these reforms have been largely parametric, with policy relying on incrementalism to move towards a universal pension scheme in time rather than a quick move. There seems to be very little public appetite, as manifested in public consultation exercises like the Green paper on pensions in 2007, for major structural reforms such as the move to an earnings related state pension or changes in the state retirement age.

The debate has further been developed more recently ${ }^{4}$ focusing on improved adequacy, the abolition of the retirement requirement at age 65 to allow older people to continue to contribute to the economy if they wish to do so, mandatory membership of PRSAs for all workers and a review of the generous tax relief for private pension provision which costs a similar amount as the social welfare pension. The Green Paper on Pensions, 2007 discusses different policy options including the introduction of universal pensions, reforming and back-dating the homemaker's scheme, replacing the average contribution test with a total contribution approach and miscellaneous issues relating to social welfare pensions including indexing, the existence of two contributory pension schemes, social insurance for spouses of farmers/self employed. The Green Paper also considers the introduction of a mandatory or soft-mandatory supplementary pension scheme.

\footnotetext{
${ }^{3}$ The NPPI has been launched in order to facilitate national debate on how to achieve a developed national policy system and to formulate a strategy and make recommendations for actions needed to achieve the system.

${ }^{4}$ See Submission to the National Pensions Board on the Pensions Review, Combat Poverty Agency, September, 2005.
} 
Despite these reports, reforming Ireland's pension system is still a difficult task. However, it can be made easier by understanding citizens' opinion concerning the size and shape of the welfare state and more generally, by tackling the sources of political conflict over the potential directions of reform and the different approaches to address sustainability. The different alternatives that can be considered range from maintaining the status quo to some option reforms. Note that maintaining the status quo would mean that, in the short to medium term, about 47,000 people on average would remain outside the Social Welfare pensions system (Green Paper on Pensions (2007)). The other options can be divided into enhancing Social Welfare pensions on one hand and encouraging greater personal savings through supplementary pensions on the other hand. Reforming the state pension system implies making it more generous (through improving the adequacy of the system) and less means-tested (through extending coverage). This would require higher public spending on pensions, and thus higher contribution rates. Shifting away from the usual Anglo-Saxon type and implementing earnings-related pension benefits can also be considered. The choice experiment aims at evaluating these reform options from the citizens' point of view.

\section{Modelling State Pension System Preferences}

How different variables affect people's evaluation of the public pension system? Political economy literature on the determination of pension systems' parameters models individuals' preferences in an overlapping generation setting, where agents choose the values of the parameter(s) through maximizing their utility function over the life cycle. In line with this strand of the literature, we introduce a life-cycle model of pension preferences involving a number of choices:

- the level of the contribution rate;

- the size of the pension benefit;

- how benefits are redistributed;

- the eligibility age for the benefit; and

- the resulting poverty rate among the elderly induced by the pension system chosen.

We consider a two-periods overlapping generation model. Individuals are successively active (18-64 years) then retired (older than 65 years). In addition to age distinction, respondents also differ in revenue endowment. For simplicity we assume that the society consists of two groups of individuals. An individual of type $i$ is characterized by his exogenous income level: $w_{i}, i=m-; m+$ with $m-$ for below the median income, $m+$ for above the median income ${ }^{5}$. Each individual enters working activity at time 0 , retires at date $1-l^{\circ}$ and lives until time 1 . We note $C_{i}^{g}$ the discounted lifetime income of the respondent of generation $g(g=y, o)$ and income group $i(i=m-; m+)$. See Table 1 for a definition of the lifetime income of each group.

The lifetime budget constraint of an old agent is given by:

$C_{i}^{o}=c_{i}^{o}+(1+\rho) c_{i}^{y^{\prime}}=l^{o} b_{i}^{o}+(1+\rho) c_{i}^{y^{\prime}}$

The lifetime budget constraint of the young agents is given by:

\footnotetext{
${ }^{5}$ The annual individual mean income for the sample is $€ 16699$ and the annual individual median income is $€ 14000$.
} 


$$
C_{i}^{y}=c_{i}^{y}+\frac{C_{i}^{o^{\prime}}}{1+\rho}=\left(1-l^{o}\right) w_{i}(1-\tau)+\frac{1}{1+\rho} c_{i}^{o^{\prime}}
$$

$l^{o}$ represents lifetime leisure, it represents the period spend in retirement, $\rho$ is a discount factor, $\tau$ is the contribution rate to the state pension scheme, it determines the generosity of the system. In order to concentrate on the redistributive feature of the pension system, we do not consider explicitly the possibility to redistribute income through another tax. $c_{i}^{o}$ is consumption during old age and $c_{i}^{y}$ is consumption during youth. $b_{i}^{o}$ is the level of the state pension benefit for an old individual $i$.

\section{Table 1}

Definition of the revenues of the different groups

\begin{tabular}{|l|l|l|}
\multicolumn{1}{c|}{} & \multicolumn{2}{c|}{ Pension benefit } \\
\cline { 2 - 3 } & $\begin{array}{l}\text { Below median } \\
\text { income }\end{array}$ & $\begin{array}{l}\text { Above median } \\
\text { income }\end{array}$ \\
\hline Young & $\frac{b_{m-}^{o^{\prime}}}{1+\rho}$ & $\frac{b_{m+}^{o^{\prime}}}{1+\rho}$ \\
\hline Old & $b_{m-}^{o}$ & $b_{m+}^{o}$ \\
\hline
\end{tabular}

\begin{tabular}{|l|l|l|}
\multicolumn{1}{c|}{ Consumption } \\
\cline { 2 - 3 } & $\begin{array}{l}\text { Below median } \\
\text { income }\end{array}$ & $\begin{array}{l}\text { Above median } \\
\text { income }\end{array}$ \\
\hline Young & $c_{m-}^{y}+\frac{c_{m-}^{o^{\prime}}}{1+\rho}$ & $c_{m+}^{y}+\frac{c_{m+}^{o^{\prime}}}{1+\rho}$ \\
\hline Old & $C_{m-}^{o}+(1+\rho) c_{m}^{y^{\prime}}$ & $C_{m+}^{o^{\prime}}+(1+\rho) c_{m}^{y}$ \\
\hline
\end{tabular}

A representative individual of generation $g$ and ability $i$ maximises a utility function $U_{i}^{g}\left(C_{i}^{g}\right)$. Individuals are assumed to be altruistic, that is, they derive utility not only from their own lifetime consumption and leisure but also from the consumption enjoyed by the elderly of the opposite income group, and from preferences regarding the poverty rate among the elderly. That is, a representative individual votes over the pension benefit they would receive from the state pension system, but also on what the current pensioners receive. Indeed, individuals are not purely selfish and they might dislike outcomes that induce high poverty among the elderly, they are poverty averse (or inter-generationally inequality averse). Poverty aversion has an impact on the "size" of the state pension scheme, that is, on "how much is distributed". Furthermore, they have distributional preferences over the public pension system (they might be intra-generationally inequality averse). Attitudes to inequality have impact on "how pensions are distributed", that is, whether pension benefits are means-tested; universal or earnings-related (see Figure 2).

The maximization problem of the old generation is given by:

$$
\max _{C_{i}^{o}} U_{i}^{o}=\alpha_{i}^{o} C_{i}^{o}\left(b_{i}^{o}, \tau\right)+\beta_{i}^{o}\left(l^{o}\right)+\gamma_{i}^{o} \operatorname{Pov}\left(c_{m+}^{o}, c_{m-}^{o}, \tau\right)+\theta_{i}^{o} u\left(c_{k}^{o}\right)
$$

Similarly, the maximization problem of the young generation is given by:

$$
\max _{C_{i}^{y}} U_{i}^{y}=\alpha_{i}^{y} C_{i}^{y}\left(\tau, b_{i}^{o^{\prime}}\right)+\beta_{i}^{y} l^{o^{\prime}}+\gamma_{i}^{y} \operatorname{Pov}\left(c_{m+}^{o}, c_{m-}^{o}, \tau\right)+\theta_{i}^{y} u\left(c_{k}^{o}\right)
$$

$k=m-, m+, \quad k \neq i . \quad \alpha_{i}^{g}$ is the preference parameter associated with lifetime consumption. Pov is the current poverty rate among the elderly. $\gamma_{i}^{g}$ indicates the effect of 
poverty aversion. Individual feel poverty aversion if $\gamma_{i}^{g}<0 . \theta_{i}^{g}$ is the parameter preference for the level of the state pension benefit for the elderly of the other income group.' refers to the next period variable for the young and the former period variable for the old.

\section{Figure 2}

Degree of redistribution of the state pension system
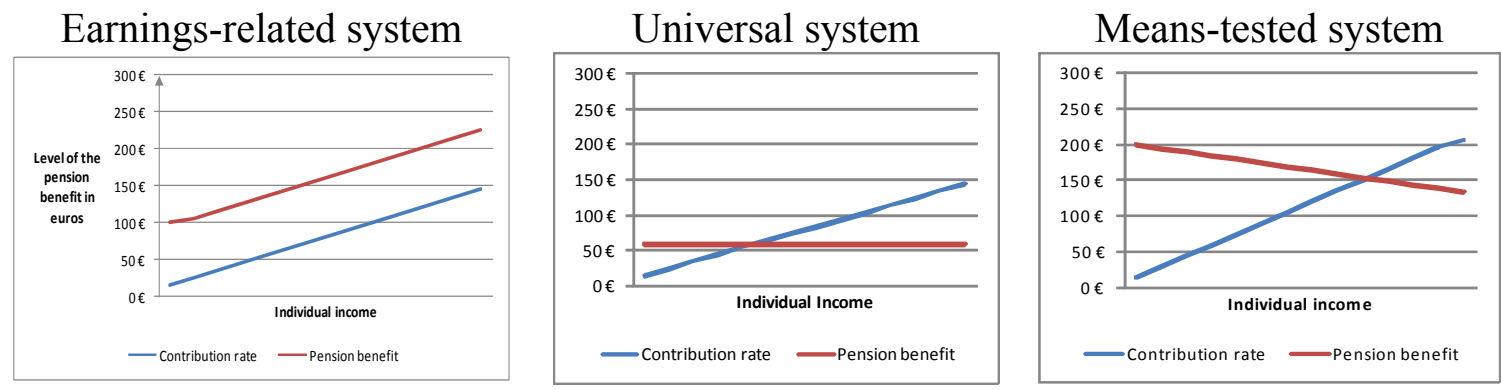

Usually, income is allocated between consumption and saving through a maximisation process of the inter-temporal utility. However, neither data on consumption, nor on saving are available. Therefore, income, during the first period of life is used as a proxy for consumption. We suppose that actual income is equal to disposable income minus taxes (apart from contributions to pensions) and saving. We further assumed that only public pension benefits compose retirement income. This is a restrictive hypothesis as $52.9 \%$ of respondents from the sample are members of a private scheme.

The specification above (equations (3) and (4)) implies the estimation of four conditional logit models (see Section 6). The estimation process of the utility model allows testing empirically hypothesis built up from previous literature on demand for redistribution. The question behind the different hypothesis is: what are the forces behind people's preferences for redistribution by the public pension system? The estimation of the life cycle model allows assessing the explanatory power of three different effects. The first hypothesis relates to the income effect, also presented as the "homo economicus effect" in Corneo and Grüner (2002). The first argument stipulates that Income is an important determinant in people's evaluation of the public pension system as respondents are egoistic and will choose the pension alternative that increases their pecuniary gains. The second hypothesis relates to age. Following the assumption made by many political economy models in line with the seminal work of Browning (1975), the age effect suggests that the older the respondent, the more they will choose a higher contribution rate to the public pension system. Similarly, pensioners (who benefit the most from the state pension system) are the more in favour of maintaining the current system and against the "retrenchment" of the welfare state. Hamil-Luker (2001) analyzes the impact of age on public opinion toward government spending on old age assistance and finds that age doesn't have a strong explanatory power. Finally, the value orientation effect suggests that respondents' attitudes towards redistribution through the state pension system are determined by their degree of inequality aversion which stipulates that individuals are inequality averse, independently from their economic status (see Bowles and Gintes (2000)). This is justified by individuals' altruistic preferences. 
Given the hypothesis just mentioned, we are interested in studying how changes in the relevant parameters of the model affect the utility of the different groups in society. Table 2 and Table 3 present some comparative statics properties of the model. The aim is to examine how given utilities change in response to changes in parameters of the variables.

Table 2

Comparative statics of the attributes of the pension system on individual preferences

\begin{tabular}{|l|c|c|c|c|l|l|l|}
\hline Utility & POV & \multicolumn{7}{c|}{$b_{m+}$} & $b_{m-}$ & \multicolumn{2}{c|}{$\tau$} & $l^{o}$ \\
\hline & \multicolumn{7}{|c|}{ First derivatives } \\
\hline$U_{m-}^{o}$ & - & + & & + & - & + \\
\hline$U_{m+}^{o}$ & - & + & & + & - & + \\
\hline$U_{m-}^{y}$ & - & + & & + & - & + \\
\hline$U_{m+}^{y}$ & - & + & & + & - & + \\
\hline
\end{tabular}

Table 3

Comparison of first derivatives

\begin{tabular}{|l|l|l|l|l|}
\hline$\frac{\partial U_{m-}^{o}}{\partial P o v}<\frac{\partial U_{m+}^{o}}{\partial P o v}$ & $\frac{\partial U_{m+}^{o}}{\partial b_{m+}}>\frac{\partial U_{m+}^{y}}{\partial b_{m+}^{\prime}}$ & $\frac{\partial U_{m+}^{o}}{\partial b_{m-}}<\frac{\partial U_{m+}^{o}}{\partial b_{m+}}$ & $\frac{\partial U_{m+}^{o}}{\tau}>\frac{\partial U_{m+}^{y}}{\tau}$ & $\frac{\partial U_{m+}^{o}}{l_{m+}^{o}}<\frac{\partial U_{m+}^{y}}{l_{m+}^{o}}$ \\
\hline$\frac{\partial U_{m-}^{y}}{\partial P o v}<\frac{\partial U_{m+}^{y}}{\partial P o v}$ & $\frac{\partial U_{m-}^{o}}{\partial b_{m-}}>\frac{\partial U_{m-}^{y}}{\partial b_{m-}}$ & $\frac{\partial U_{m-}^{o}}{\partial b_{m-}}>\frac{\partial U_{m-}^{o}}{\partial b_{m+}}$ & $\frac{\partial U_{m-}^{o}}{\tau}>\frac{\partial U_{m-}^{y}}{\tau}$ & $\frac{\partial U_{m-}^{o}}{l_{m-}^{o}}<\frac{\partial U_{m-}^{y}}{l_{m-}^{o}}$ \\
\hline & $\frac{\partial U_{m+}^{y}}{\partial b_{m-}}<\frac{\partial U_{m+}^{y}}{\partial b_{m+}^{\prime}}$ & $\frac{\partial U_{m+}^{o}}{\tau}<\frac{\partial U_{m-}^{o}}{\tau}$ & \\
\hline & $\frac{\partial U_{m-}^{y}}{\partial b_{m-}}>\frac{\partial U_{m-}^{y}}{\partial b_{m+}^{\prime}}$ & $\frac{\partial U_{m+}^{y}}{\tau}<\frac{\partial U_{m-}^{y}}{\tau}$ & \\
\hline
\end{tabular}

\section{Theoretical basis of Discrete Choice Experiments}

The demand for reforming the public Irish pension system is assessed through using and extending a particular stated preferences method: choice experiment; conducted to value individuals' preferences regarding the parameters of the Irish public pension system, more precisely through estimating preferences for alternative pension systems (meanstested, universal or earnings-related) as a function of the system attributes and individuals' characteristics and attitudes.

Discrete CEs have widely been used in the literature since their introduction in the marketing and transport fields by Louviere and Hensher (1982) and Louviere and Woodworth (1983). They have now been widely applied in many areas, such as the environmental economics literature (Blamey et al. (1999)), recreation (Hanley et al. (2002)), health (Hall et al. (2004)), transport economics and marketing (See Hensher (1994) and Louviere (1994) for an overview of the use of choice modeling in the field of transportation and marketing respectively). However, the use of stated preferences techniques in the field of pensions is still scarce. Discrete choice experiments are consistent with the Lancasterian microeconomic approach (Lancaster (1966)) whereby 
individuals derive utility from the attributes of a good rather than the good itself. In choice experiments, each respondent is typically presented with several choice sets, each containing a set of alternative public goods - in our case alternative public pension systems - defined in terms of their attributes at specified levels. Each alternative being a different combination of the attributes and their levels constructed following a given experimental design Respondents are then asked to choose their most preferred alternative. They are assumed to choose the option that provides them with the highest utility value. A baseline alternative (or status quo) is usually included in each choice set. Typically, five to eight choice sets are included in a choice experiment. The choice experiment reported in this paper contains alternatives that describe hypothetical, constructed potential State pension systems in order to analyze people's preferences for different kinds of public pension provisions, each implying a different degree of redistribution. The hypothetical scenarios were constructed in such a way to be as realistic as possible.

CE finds its theoretical basis in the random utility model (Thurstone (1927); McFadden (1974)), which models choices as a function of attributes and their levels. According to the Random Utility Theory (RUT), the indirect utility function that an individual $k$ allocates to one alternative $i\left(U_{k i}\right)$ is decomposed into two parts: a deterministic part $\left(V_{k i}\right)$ which is typically assumed to be linear and additive in the attributes $(x)$ of the $A$ different alternatives in the choice set, and a stochastic element $(\varepsilon)$ which represents the unobservable influences on individual choice.

The indirect utility function associated with alternative $i$ for an individual $k$ can be written:

$U_{k i}=V_{k i}\left(x_{k i}\right)+\varepsilon_{k i}=\beta x_{k i}+\varepsilon_{k i}$

Where $\beta$ represents the vector of preference parameters (coefficients) associated with the vector of attribute levels $x_{i}$

The probability that respondent $k$ prefers option $i$ to any option $j$ in the choice set can be expressed as the probability that the utility associated with alternative $i$ exceeds that associated with all other alternatives:

$$
P\left[\left(U_{k i}>U_{k j}\right) \forall i \neq j\right]=P\left[\left(V_{k i}-V_{k j}\right)>\left(\varepsilon_{k j}-\varepsilon_{k i}\right)\right]
$$

Assuming that the error terms are independently and identically distributed (IID) with an extreme-value (Weibull) distribution implies that the probability of any particular alternative $i$ being chosen as the most preferred can be expressed in terms of the logistic distribution (McFadden (1973)). The following specification is known as a conditional logit model:

$$
P\left(U_{k i}>U_{k j}, \forall i \neq j\right)=\frac{\exp \left(\mu V_{k i}\right)}{\sum_{j \in A} \exp \left(\mu V_{k j}\right)}
$$

Where $\mu$ is a scale parameter, inversely proportional to the standard deviation of the error distribution. $\mu$ is commonly normalized to one (Ben-Akiva and Lerman (1985)). The independence of the Weibull error terms across the different options contained in the 
choice set implies that specification (3) obeys the Independence from Irrelevant Alternatives (IIA) property (or Luce's Choice Axiom; see Luce (1959)) which states that the relative probabilities of two options being selected are unaffected by the introduction or removal of other alternatives. That is to say that the error terms are uncorrelated between choices and have the same variance (Carson et al. (1994)). Violations of the IIA assumption can be tested using a test developed by Hausman and McFadden (1984). If a violation of the IIA hypothesis is observed, then more complex statistical models, that relax some of the assumptions used, are necessary. Such models are the random parameters logit model (Train (1998)) or the nested logit model (McFadden (1978)). The latter allows for correlations among the error terms within classes of alternatives. The most common method for estimating the parameters of the model is the maximum likelihood.

Welfare measures, and more specifically Willingness to Pay (WTP) compensating variation welfare measure that conforms to demand theory, can then be derived.

$W T P=\beta_{y}^{-1} \ln \left\{\frac{\sum_{k} \exp \left(V_{k}^{1}\right)}{\sum_{k} \exp \left(V_{k}^{0}\right)}\right\}$

$V^{0}$ is the utility of the initial state and $V^{1}$ the utility of the alternative state.

$\beta_{y}$ represents the marginal utility of income and is the coefficient of the cost attribute.

The value of a marginal change in any of the attributes can be expressed as the ratio of coefficients given in the estimation of (7), where $\beta_{c}$ is the coefficient on any of the attributes. These ratios are often known as implicit prices:

$W T P=\frac{-\beta_{c}}{\beta_{y}}$

In order to apply the RUT to our study framework, different attributes have been selected to describe the Irish State pension system, these are described in Table 4. 
Table 4

Definition of the choice specific attributes

\begin{tabular}{|l|l|}
\hline \multicolumn{1}{|c|}{ Attributes } & \multicolumn{1}{c}{ Description } \\
\hline lo_pen & Weekly State Pension for a low income individual \\
\hline hi_pen & Weekly State Pension for a high income individual \\
\hline cost & Weekly contribution to finance State pensions for the average wage \\
\hline pov & Poverty rate among the elderly \\
\hline ret_age & Minimum retirement age (years) \\
\hline
\end{tabular}

The baseline empirical specification is given by the indirect utility (10). Several variants will be presented in section 6 .

$V_{k i}=\beta_{1} l_{-}$pen $_{i}+\beta_{2} h i_{-}$pen $_{i}+\beta_{3} \cos t_{i}+\beta_{4}$ pov $+\beta_{5}$ ret_age ${ }_{i}$

\section{Survey Instrument Design and Sample Characteristics}

\subsection{Questionnaire and sampling design}

The survey instrument has been developed following several rounds of testing, involving one pilot test, individual interviews, discussions with $\mathrm{PhD}$ students and one focus group composed of participants from the general public. The resulting questionnaire is structured in three parts: Part I: Attitudinal questionnaire; Part II: Choice Experiment; and, Part III: Socio-economic questionnaire. The choice experiment aims at investigating attitudes towards the current Irish state-run pension system and towards some of the likely reforms resulting from the modification of the parameters of the system and involving changes in its principles, degree of redistribution, type of redistribution and poverty among the elderly. As shown in Table 5, five attributes have been selected for valuation. The first attribute is the weekly state pension benefit for a working individual at two third the average earning (low income worker). The second attribute is the weekly state pension benefit for a working individual at three times the average earning (high income worker). The weekly state pension for a low income individual takes on five different levels, among which the first corresponds to the actual state benefit. The levels of the weekly state benefit for a high income individual vary accordingly to describe either a means-tested, a universal or an earnings-related system. The third attribute is the cost one and corresponds to the weekly contribution amount required to finance state pension benefits for an average individual worker. The fourth attribute is the poverty rate among the elderly implied by each alternative system. Finally, the fifth attribute is the earliest retirement age at which individuals are allowed to receive their State pension, which takes on two values, either the current retirement age: 65 years or a higher retirement age: 68 years. The attributes have been combined in eight choice sets, comprising all the alternatives allowed by the design (32 alternatives). Each choice set comprises four alternative choices. A baseline alternative corresponding to the current system is included in each choice set. An example of a choice set is given in Appendix 1. 
Table 5

Description of the attributes and levels

\begin{tabular}{|c|c|c|c|c|c|}
\hline \multirow[t]{2}{*}{ Attributes } & \multicolumn{5}{|c|}{ Levels } \\
\hline & Current situation & & & & \\
\hline $\begin{array}{l}\text { Weekly State Pension for } \\
\text { a low income individual }\end{array}$ & $\leq 210$ & 210 & 220 & 260 & 180 \\
\hline $\begin{array}{l}\text { Weekly State Pension } \\
\text { for a high income } \\
\text { individual }\end{array}$ & $\leq 210$ & $210,0,500$ & $220,0,520$ & $260,0,620$ & $180,0,430$ \\
\hline \multirow[t]{3}{*}{$\begin{array}{l}\text { Weekly contribution to } \\
\text { finance State pensions for } \\
\text { the average wage }\end{array}$} & $€ 30-35$ & $€ 35-40$ & $€ 40-45$ & $€ 45-50$ & $€ 30-35$ \\
\hline & & $€ 15-20$ & $€ 15-20$ & $€ 20-25$ & $€ 10-15$ \\
\hline & & $€ 50-55$ & $€ 55-60$ & $€ 65-70$ & $€ 45-50$ \\
\hline \multirow[t]{2}{*}{$\begin{array}{l}\text { Poverty rate among the } \\
\text { elderly }\end{array}$} & Medium $(10 \%-15 \%)$ & Low $(5 \%-10 \%)$ & Very low $(<5 \%)$ & Very low $(<5 \%)$ & Medium $(10 \%-15 \%)$ \\
\hline & & High $(15 \%-20 \%)$ & Medium $(10 \%-15 \%)$ & & Very high $(20 \%-25 \%)$ \\
\hline $\begin{array}{l}\text { Minimum retirement } \\
\text { age (years) }\end{array}$ & 65,68 & 65,68 & 65,68 & 65,68 & 65,68 \\
\hline
\end{tabular}

The Sampling strategy was designed so as to obtain a representative sample of the Irish population. The questionnaires were administered using door-to-door technique. In most of the cases, and in accordance with respondents' wishes, the questionnaires were dropped off and collected according to an arranged time. The sampling approach for the survey followed a two-stage procedure. Sampling was first stratified according to the two principle Irish areas classification: Urban/Rural. The second stage involved the choice of locations that are representative of the Irish population in terms of age, gender and socioeconomic status. The survey was administered to a representative sample of 498 respondents drawn from the adult Irish population entitled to vote (persons aged 18 years and over). At the end, 326 questionnaires were ready to analyze. The overall response rate of the survey was 65 percent. Table 6 shows the sample age ranges proportions as compared to the national proportions. 
Table 6

Proportions of the different age ranges in the total population (sample and national proportions)

\begin{tabular}{|c|c|c|c|c|c|c|c|}
\hline \multirow[b]{2}{*}{ Area } & \multicolumn{6}{|c|}{ age range } & \multirow[b]{2}{*}{ Total } \\
\hline & 18 to 24 & 25 to 34 & 35 to 49 & 50 to 59 & 60 to 69 & 70 or more & \\
\hline \multicolumn{8}{|l|}{ Urban } \\
\hline Number of respondents & 54 & 31 & 36 & 32 & 28 & 19 & 200 \\
\hline $\begin{array}{l}\text { Percentage in the total sample of the same age } \\
\text { range }\end{array}$ & 78.26 & 62.00 & 48.65 & 58.18 & 60.87 & 59.38 & 61.35 \\
\hline \multicolumn{8}{|l|}{ Rural } \\
\hline Number of respondents & 15 & 19 & 38 & 23 & 18 & 13 & 126 \\
\hline $\begin{array}{l}\text { Percentage in the total sample of the same age } \\
\text { range }\end{array}$ & 21.74 & 38.00 & 51.35 & 41.82 & 39.13 & 40.63 & 38.65 \\
\hline \multicolumn{8}{|l|}{ Total } \\
\hline Number of respondents & 69 & 50 & 74 & 55 & 46 & 32 & 326 \\
\hline Percentage in the total population sample & 21.17 & 15.34 & 22.7 & 16.87 & 14.11 & 9.82 & 100 \\
\hline \multicolumn{8}{|l|}{ National proportions in the population aged } \\
\hline 15 ye ars and over $(\%)$ & 18.75 & 21.40 & 26.61 & 14.00 & 9.63 & 9.61 & 100 \\
\hline $\begin{array}{l}\text { National proportions in the total population } \\
(\%)\end{array}$ & 14.92 & 17.04 & 21.18 & 11.14 & 7.67 & 7.65 & 100 \\
\hline
\end{tabular}

Note: National proportions for the age group 18 to 24 years corespond to the proportions of the age group 15-24.

\subsection{Descriptive statistics for the sample}

\subsubsection{Profile and main characteristics of the survey respondents}

Age is an important variable within the framework of this analysis as pension policy is mainly a "generational" issue. The age distribution of the survey reflects that of the gender population, with around $23 \%$ in the 35-49 years age range, which is the largest percentage of any of the age groups. The majority of respondents are male: $52 \%$ against and a majority, (47\%) attained at least a recognized third level education level. Among respondents, $51 \%$ are married. $24 \%$ of the individuals live in a household composed of 2 persons, whilst $21 \%$ live in a household composed of 4 persons. A majority $(27 \%)$ of respondents are private sector employees, while $17 \%$ are retired. For $63 \%$, the main household income source is employment, which is the largest proportion of all sources of income, $11 \%$ of respondents belong to a household that relies mainly on public pensions for its income and $8 \%$ on social welfare. $22 \%$ have or have had elderly relatives living in their households.

We expect that pensioners, individuals belonging to a household that derives a large share of his income from public pensions, and individuals who have had elderly relatives living in their households are more likely to oppose retrenchment of public pensions than those who are less dependent on welfare state programs ${ }^{6}$. This hypothesis comes from Pierson's "new politics of the welfare state" which posits that social transfer programs generate self-interested beneficiary groups who will act politically to defend their "programs". This is particularly true for the retirees as they almost completely rely on

${ }^{6}$ Lynch (2006) tests this hypothesis. 
pensions. Income should have a strong explanatory power in explaining individuals' choices (In accordance with the Meltzer and Richard model). A majority (28.5\%) belong to a household earning between $€ 20000$ and $€ 40000$ a year before taxes and $22 \%$ to a household earning between $€ 40000$ and $€ 60000$ a year.

\subsubsection{Attitudinal profile of the survey sample}

People's knowledge about the functioning of the pension system seems to be an age issue implying that the older the respondent, the more they are informed about how the pension system operates and about the level of the pension benefit it provides. While in general, very few people are very well informed $(17 \%)$, the majority of retirees $(+50 \%)$ is very well informed. This result is also available for people's knowledge about their (likely) retirement income. We expect better informed voters to be more likely to favour reforms (See Boeri et al. (2001)).

$41 \%$ of respondents are in favour of a higher pension benefit for the poor (equivalent to a means-tested system) and $37 \%$ are in favour of the same pension benefit for everyone (universal system). Only $20 \%$ of individuals are in favour of earnings-related pension system. Among these, $51 \%$ are respondents who belong to the highest income band, this same income group is the least in favour of the other systems proposed.

Respondents were further presented with three options to deal with demographic ageing. The solution that seems to be the most popular is increasing the retirement age followed by saving more for retirement. The solution that is the least popular is that the government spends more on pensions. Respondents were also asked how they agree with three pension principles. The majority of respondents $(36 \%)$ strongly disagree with the principle that it is an individual responsibility to save for old age. $47 \%$ of respondents strongly agree with the fact that it is the government responsibility to provide each pensioner with a pension benefit. Finally, $41 \%$ of respondents slightly agree that the way the pension benefit is provided in Ireland should remain the same, and $31 \%$ of respondents strongly disagree with this statement. The general idea from this question is that the status quo (maintaining the current state pension system) is not the preferred option; still a great majority of individuals thinks it is the government responsibility to provide each pensioner with a state pension benefit. Concerning the way to pay for the pension benefit, a large majority of respondents $(66 \%)$ choose the option: the richer pay proportionally more than the poorer, which suggests that respondents opt for a progressive contribution system. 
Table 7

Attitudinal Profile of the Respondents

\begin{tabular}{|c|c|c|}
\hline & Frequency & Percent \\
\hline \multicolumn{3}{|l|}{ Differences in income in Ireland are too large ... } \\
\hline strongly agree & 135 & 41.41 \\
\hline slightly agree & 108 & 33.13 \\
\hline strongly disagree & 13 & 3.99 \\
\hline slightly disagree & 27 & 8.28 \\
\hline neither agree nor disagree & 21 & 6.44 \\
\hline \multicolumn{3}{|l|}{ Overall, would you be in favour of... } \\
\hline less inequality and more tax & 130 & 39.88 \\
\hline more inequality and less tax & 44 & 13.50 \\
\hline An unchanged amount of taxes and same level of inequality & 62 & 19.02 \\
\hline \multicolumn{3}{|l|}{$\begin{array}{l}\text { It is the responsibility of the government to reduce the } \\
\text { differences in income... }\end{array}$} \\
\hline strongly agree & 118 & 36.20 \\
\hline slightly agree & 97 & 29.75 \\
\hline strongly disagree & 42 & 12.88 \\
\hline slightly disagree & 29 & 8.90 \\
\hline neither agree nor disagree & 18 & 5.52 \\
\hline
\end{tabular}

Besides specific questions on pensions, we also surveyed general attitudes towards the welfare state and demand for redistribution. Concerning income inequality in Ireland, a majority (more than 41\%) of respondents strongly agree with the statement "differences in income in Ireland are too large" (Table 7). A clear majority $(39.5 \%)$ are in favour of less inequality and more tax. A higher proportion of individuals also strongly agree with the fact that it is a governmental responsibility to reduce income inequality.

\section{Estimated models and Results}

In this section, we report the conditional logit models used to estimate the Random Utility Model (RUM) constructed to assess preferences for alternative state pension systems. The selected choice specific attributes are used to specify the utility of each pension alternative. The models presented below were estimated with STATA using Maximum Likelihood estimation procedures. Several Conditional logit (CL) models have been estimated. The first set of models includes only choice specific attributes and the second set adds individual specific characteristics.

\subsection{Definition of the Baseline Specifications}

We begin by showing four specifications. The four different variants seem satisfactory both on the economic and statistical side. Obviously, the poverty rate among the elderly has a strong effect on people's evaluation of the public pension system.

In a first attempt, not reported in the table below, we run a Conditional Logit model, with only regressors the attributes of choices (see equation (10) above). Results show that the estimate of the cost attribute is positive and the estimates of the attributes "level of the 
pension benefit for a low income individual" (henceforth low pension) and "level of the pension benefit for a high income individual" (henceforth high pension) are negative. We then estimate a non linear utility function by introducing the square values of cost, poverty, low pension and high pension.

The utility function retained is defined as follows:

$V_{k i}=\beta_{1} l o_{-}$pen $_{i}+\beta_{2} l_{-}$pen $_{i}^{2}+\beta_{3} h i_{-}$pen $_{i}+\beta_{4} h i_{-} p e n_{i}^{2}+\beta_{5} \cos t_{i}+\beta_{6} \cos t_{i}^{2}$

$+\beta_{7}$ pov $+\beta_{8}$ pov $^{2}+\beta_{9}$ ret_age $e_{i}$

Model 1 (CL1) in Table 8 represents the above basic non linear specification. All the coefficients are different from zero at the 1 percent significance level with the exception of the square value of poverty and of the attribute retirement age. The signs of the attributes are as expected. A higher level of the low pension increased the probability that a pension scheme alternative would be chosen, as did the high pension but at a much lower magnitude. Greater poverty and higher cost reduced the choice probability of choosing the associated state pension scheme. A retirement age above the existing one also decreased the probability of the option being chosen. This last effect is however not significant.

\subsubsection{Introducing alternative specific constants}

In a second model (CL2), we introduce Alternative Specific Constants (ASC's). The number of the ASCs depends on the number of alternatives in a choice set. As we have four alternatives in each choice set, the first alternative being the status-quo, we estimate a set of three ASCs. The ASCs show the effect of asymmetric but unobserved factors of respondents' choices (Morrison et al. (2002)). ASCs explain why respondents chose a different pension system apart from changes in the attributes that were presented to them in the choice experiment.

The indirect utility associated with choosing alternative $i$ is given by:

$V_{k i}=\beta_{1} l_{-}$pen $_{i}+\beta_{2} l o_{-}$pen $_{i}^{2}+\beta_{3} h i_{-}$pen $_{i}+\beta_{4} h i_{-}$pen $_{i}^{2}+\beta_{5} \cos t_{i}+\beta_{6} \cos t_{i}^{2}$

$+\beta_{7}$ pov $+\beta_{8}$ pov $^{2}+\beta_{9}$ ret_age ${ }_{i}+\beta_{10}$ ASC $_{2}+\beta_{11}$ ASC $_{3}+\beta_{12}$ ASC $_{4}$

The parameters associated with the ASCs are positive and significant at the 1 percent significance level. Similarly, all variables (apart from the retirement age) are significant and of the expected signs.

A utility function considering the alternative of choosing the status quo has been estimated (CL3). A new variable, Alternative0, has been created:

$V_{k i}=\beta_{1} l_{-}$pen $_{i}+\beta_{2} l o_{-}$pen $_{i}^{2}+\beta_{3} h i_{-}$pen ${ }_{i}+\beta_{4} h i_{-}$pen $_{i}^{2}+\beta_{5} \cos t_{i}+\beta_{6} \cos t_{i}^{2}$

$+\beta_{7}$ pov $+\beta_{8}$ pov $^{2}+\beta_{9}$ ret_age $+\beta_{10}$ Alternative 0

The Alternative Specific Constant is specified to equal 0 when Alternative A, B or C was selected and to 1 when the "status quo" option was chosen. The alternative specific to the status quo is negative and significant at the 1 percent significance level, meaning that choosing the current pension scheme decreases utility.

\subsubsection{Introducing pension system type}


Three variables have been created to account for individuals' choices regarding different kinds of financing state pensions implying different kinds of redistribution: means-tested, universal and earnings-related. The model that has been estimated is given by the following indirect utility function (CL4):

$V_{k i}=\beta_{1} l_{\text {lo }}$ pen $_{i}+\beta_{2} h i_{-}$pen $_{i}+\beta_{3} \cos t_{i}+\beta_{4}$ pov $+\beta_{5}$ ret_age ${ }_{i}$

$+\beta_{6}$ means_tested $+\beta_{7}$ universal $+\beta_{8}$ earnings_related

Table 8

Random utility pension choice: Models 1-4

\begin{tabular}{|c|c|c|c|c|}
\hline Actual Choice & CL1 & CL2 & CL3 & CL4 \\
\hline State pension benefit & 0.136 & 0.148 & 0.165 & 0.013 \\
\hline for a low income individual & $(6.38)^{* *}$ & $(4.97)^{* *}$ & $(7.25)^{* *}$ & $(3.12)^{* *}$ \\
\hline \multirow[t]{2}{*}{ Low pension-squared } & -0.0002 & -0.0002 & -0.0003 & \\
\hline & $(-6.08) * *$ & $(-4.37)^{* *}$ & $(-6.63) * *$ & \\
\hline State pension benefit & 0.012 & 0.037 & 0.037 & 0.003 \\
\hline for a high income individual & $(5.71)^{* *}$ & $(5.87)^{* *}$ & $(5.88)^{* *}$ & $(1.11)$ \\
\hline \multirow[t]{2}{*}{ High-pension-squared } & -0.00001 & -0.00003 & -0.00003 & \\
\hline & $(-7.27) * *$ & $(-7.07)^{* *}$ & $(-7.08) * *$ & \\
\hline \multirow[t]{2}{*}{ Poverty rate among the elderly } & -11.078 & -17.486 & -16.775 & -4.254 \\
\hline & $(-3.88) * *$ & $(-4.79) * *$ & $(-5.36) * *$ & $(-3.28)^{* *}$ \\
\hline \multirow[t]{2}{*}{ poverty-squared } & 6.834 & 8.020 & 7.535 & \\
\hline & $(0.61)$ & $(0.64)$ & $(0.67)$ & \\
\hline Cost for an average & -0.149 & -0.459 & -0.452 & -0.039 \\
\hline worker & $(-4.32) * *$ & $(-5.76)^{* *}$ & $(-5.67) * *$ & $(-1.14)$ \\
\hline \multirow[t]{2}{*}{ Cost-squared } & 0.0013 & 0.002 & 0.002 & \\
\hline & $(3.60)^{* *}$ & $(5.70)^{* *}$ & $(5.59)^{* *}$ & \\
\hline \multirow[t]{2}{*}{ Retirement age } & -0.016 & -0.020 & -0.022 & -0.041 \\
\hline & $(-0.94)$ & $(-1.08)$ & $(-1.33)$ & $(-2.39)^{*}$ \\
\hline \multirow[t]{2}{*}{ Alternative 2} & & 1.179 & & \\
\hline & & $(4.96)^{* *}$ & & \\
\hline \multirow[t]{2}{*}{ Alternative 3} & & 1.099 & & \\
\hline & & $(4.37)^{* *}$ & & \\
\hline \multirow[t]{2}{*}{ Alternative 4} & & 1.026 & & \\
\hline & & $(4.03)^{* *}$ & & \\
\hline Alternative 1 & & & -0.912 & \\
\hline (current situation) & & & $(-4.18) * *$ & \\
\hline \multirow[t]{2}{*}{ Means-tested pension alternative } & & & & -0.605 \\
\hline & & & & $(-1.77)$ \\
\hline \multirow[t]{2}{*}{ Universal pension alternative } & & & & 0.292 \\
\hline & & & & $(1.44)$ \\
\hline \multirow[t]{2}{*}{ Earnings-related pension alternative } & & & & -1.219 \\
\hline & & & & $(-2.84)^{* *}$ \\
\hline log likelihood & -3022.21 & -3012.12 & -3013.40 & -3048.10 \\
\hline
\end{tabular}


Following CL4, a universal pension scheme increases utility whereas a means-tested or an earnings-related pension scheme reduces the probability of the alternative to be selected. However choosing a universal pension scheme is not significant. Also, introducing these variables reduces the significance of the model as the high pension and cost are not significant.

All four models predict the expected effects of the pension attributes on the utility of respondents. The levels of the pension benefits (low and high) increase utility associated with the alternative. Cost, retirement age and poverty decrease the probability of the alternative to be chosen. However, what is striking is the strength of the poverty rate in reducing utility. This suggests that individuals are highly poverty averse and are in favour of a system that leads to the lowest poverty rate among the elderly.

\subsection{Accounting for respondents' heterogeneity in the choice modelling}

In a further step, we propose four groups of models that allow for taking into account respondents' heterogeneity by introducing differences between individuals into the model (Mazzanti (2003)). Specifically, we estimated the impact of age, income, social preferences and value orientation on the assessment of the Irish state pension system.

There may be several reasons why people surveyed would have a strong preference for maintaining the current public pension scheme or reform it to either a means-tested, universal or earnings-related system. The first and most advanced reason, as mentioned by the theoretical literature, refers to one's own pecuniary benefits. Assuming that people are rational utility maximizing, they should have the strongest preferences for the system that provides them with the highest financial benefit. In this respect, income should have important explanatory power. However, pecuniary self-interest has been challenged in the empirical literature as not being the main determinant of people's preferences and attitudes. Other forces might increase individuals' utility and thus imply higher demand for redistribution. In this respect, several models have been worked out to include otherregarding motives. For instance, Tabellini (2000) includes altruism from the children to their parents to describe social security systems. Age and the degree to which individuals benefit from public pensions are also expected to explain differences in preferences. Finally, inequality aversion and value orientations may be important explanatory variables. Van der Heijden et al. (1997) test empirically if altruism and fairness intervene in people's evaluation of public pensions and find strong support that both effects affect individuals' utility.

\subsubsection{Testing for Pecuniary Self-Interest}

In order to test for heterogeneity in preferences according to income, two separate conditional logit models are run for two separate groups: those reporting an annual individual income above the median annual income of the sample and those reporting an annual individual income below the median annual income. Results are given in Table 9. The first income group (column 1) contains 157 individuals whereas the second income group (column 2) contains 169 individuals. The third column shows the results of interactions between individual income and different types of pension provision.

As in all preceding models, poverty aversion plays a key role in the valuation of the public pension system. As it is expected, a higher poverty rate among the elderly reduces 
utility of the low-income individuals much more than the utility of the high income individuals, its coefficient is however not significant for the high income group. It is negative and significant at the $1 \%$ level for the low income group. A higher low pension benefit increases both the utility of the high income and of the low income group. The coefficients are positive and significant in the two cases; however, the estimated coefficient is higher for the low income group. The estimated coefficients for the high pension benefit are also positive and significant at the $1 \%$ level. The estimated coefficient is slightly higher for the high income group suggesting that the high pension benefit increases utility of the high income group more than of the low income group. These two effects give strong support to the self pecuniary argument. The estimated coefficients of the cost attribute in both income group models are of the expected sign and significant at the $5 \%$ level, however a higher contribution rate seems to decrease the utility of the high income group more than the utility of the low income group, which is a non expected result. This could be explained by the fact that the richest are not willing to pay more to have a higher pension benefit and probably count more on private pensions as suggested by the summary statistics of the attitudinal questionnaire.

The third column shows that an earnings-related pension system increases individuals' utility as their income increases. Indeed, the interaction between individual income and the earnings-related pension scheme alternative is positive and significant at the 1 percent level. This is a further support for the income effect. Introducing a universal or a meanstested pension scheme impacts utility in the opposite direction: both interactions are negative, with the interaction with the means-tested system being significant at the 1 percent level. 


\section{Table 9}

Random utility pension choice by income group

Variable Above median income Below median income Interaction with individual income

\begin{tabular}{|c|c|c|c|}
\hline State pension benefit & 0.132 & 0.141 & 0.135 \\
\hline for a low income individual & $(4.46) * *$ & $(4.55)^{* *}$ & $(6.15)^{* *}$ \\
\hline \multirow[t]{2}{*}{ Low pension-squared } & -0.0002 & -0.0002 & -0.0002 \\
\hline & $(-4.21) * *$ & $(-4.38) * *$ & $(-5.93) * *$ \\
\hline State pension benefit & 0.013 & 0.011 & 0.009 \\
\hline for a high income individual & $(4.52)^{* * *}$ & $(3.56)^{* *}$ & $(3.41)^{* *}$ \\
\hline \multirow[t]{2}{*}{ High-pension-squared } & -0.00001 & -0.00001 & -0.00001 \\
\hline & $(-5.69) * *$ & $(-4.59) * *$ & $(-5.64) * *$ \\
\hline \multirow[t]{2}{*}{ Poverty rate among the elderly } & -7.543 & -15.448 & -11.058 \\
\hline & $(-1.94)$ & $(-3.65) * *$ & $(-3.77) * *$ \\
\hline \multirow[t]{2}{*}{ poverty-squared } & -5.585 & 22.304 & 7.807 \\
\hline & $(-0.36)$ & $(1.34)$ & $(0.68)$ \\
\hline Cost for an average & -0.162 & -0.136 & -0.134 \\
\hline worker & $(-3.44)^{*}$ & $(-2.67)^{*}$ & $(-3.38) * *$ \\
\hline \multirow[t]{2}{*}{ Cost-squared } & 0.001 & 0.001 & 0.001 \\
\hline & $(2.98)^{*}$ & $(2.08) *$ & $(3.49)^{* *}$ \\
\hline \multirow[t]{2}{*}{ Retirement age } & -0.042 & 0.012 & -0.015 \\
\hline & $(-1.78)$ & $(0.48)$ & $(-0.88)$ \\
\hline Individual income ${ }^{*}$ earnings & & & 0.00001 \\
\hline related pension system & & & $(2.73)^{* *}$ \\
\hline Individual income*means-tested & & & -0.00002 \\
\hline pension system & & & $(-4.15)^{* *}$ \\
\hline Individual income*universal & & & -0.000003 \\
\hline pension system & & & $(-1.02)$ \\
\hline Log likelihood & -1613.24 & -1397.56 & $=-2870.3158$ \\
\hline
\end{tabular}

\subsubsection{Testing for Age Heterogeneity}

Separate conditional logit models have been run for two generations: the young generation (younger than 65 years) and the old generation (over 65 years). For each generation, two models have been run. The first model is the baseline model and the second one includes a variable describing the current pension scheme. Results are reported in Table 10. Almost all pension attributes are statistically significant at the $1 \%$ level for all four models. The variable indicating the retirement age was found to be statistically insignificant in all models; indeed the attribute retirement age doesn't seem to be an important determinant in people's preferences for reforming pensions. 
Table 10

Random Utility Pension Choice by Generation

\begin{tabular}{|c|c|c|c|c|}
\hline Variable & \multicolumn{2}{|c|}{ Older than 65 years } & \multicolumn{2}{|c|}{ Younger than 65 years } \\
\hline State pension benefit & 0.179 & 0.181 & 0.129 & 0.162 \\
\hline for a low income individual & $(3.16)^{* *}$ & $(3.03)^{* *}$ & $(5.58)^{* *}$ & $(6.57)^{* *}$ \\
\hline \multirow[t]{2}{*}{ Low pension-squared } & -0.0003 & -0.0003 & -0.0002 & -0.0003 \\
\hline & $(-3.06)^{* *}$ & $(-3.01)^{* *}$ & $(-5.29) * *$ & $(-5.88) * *$ \\
\hline State pension benefit & 0.022 & 0.023 & 0.010 & 0.041 \\
\hline for a high income individual & $(3.95)^{* *}$ & $(1.54)$ & $(4.44)^{* *}$ & $(5.78)^{* *}$ \\
\hline \multirow[t]{2}{*}{ High-pension-squared } & -0.00002 & -0.00002 & -0.00001 & -0.00004 \\
\hline & $(-4.13) * *$ & $(-2.13) *$ & $(-6.08) * *$ & $(-6.84) * *$ \\
\hline \multirow{2}{*}{ Poverty rate among the elderly } & -17.181 & -17.566 & -9.859 & -16.755 \\
\hline & $(-2.34)^{*}$ & $(-2.20)^{*}$ & $(-3.17)^{* *}$ & $(-4.91) * *$ \\
\hline \multirow[t]{2}{*}{ poverty-squared } & 17.293 & 17.226 & 4.668 & 5.980 \\
\hline & $(0.60)$ & $(0.59)$ & $(0.38)$ & $(0.49)$ \\
\hline Cost for an average & -0.295 & -0.3 & -0.119 & -0.484 \\
\hline worker & $(-3.34) * *$ & $(-1.65)$ & $(-3.18)^{* *}$ & $(-5.51) * *$ \\
\hline \multirow[t]{2}{*}{ Cost-squared } & 0.002 & 0.002 & 0.001 & 0.002 \\
\hline & $(2.32)^{*}$ & $(1.88)$ & $(2.84)^{* *}$ & $(5.33)^{* *}$ \\
\hline \multirow[t]{2}{*}{ Retirement age } & -0.008 & -0.009 & -0.017 & -0.025 \\
\hline & $(-0.20)$ & $(-0.21)$ & $(-0.93)$ & $(-1.34)$ \\
\hline \multirow[t]{2}{*}{ Current pension system } & & -0.065 & & -1.091 \\
\hline & & $(-0.12)$ & & $(-4.54) * *$ \\
\hline Log likelihood & -480.31 & -480.31 & -2533.87 & -2523.46 \\
\hline \multicolumn{5}{|c|}{ Value of $\mathrm{z}$ statistics in parentheses; $*$ significant at $5 \% ; * *$ significant at $1 \%$} \\
\hline \multicolumn{5}{|c|}{$\begin{array}{l}\text { When including the status quo alternative in the estimation, the variables "low pension" } \\
\text { and "cost" become insignificant for the old group, these variables remain however highly } \\
\text { significant and of the expected sign for the young group. In all cases, a higher low } \\
\text { pension benefit increases the probability of the alternative to be chosen. In fact, estimated } \\
\text { coefficients for the low pension are significant at the } 1 \% \text { level for both generations and } \\
\text { higher for the old generation. the older the respondent, the more they are in favour of an } \\
\text { expansion of the state pension system. Poverty rate among the elderly is negative and } \\
\text { significant at the } 5 \% \text { level for the old generation and at the } 1 \% \text { level for the young } \\
\text { generation. When not including the current pension system in the utility function, a } \\
\text { higher poverty rate decreases the probability of the alternative being chosen at a much } \\
\text { higher degree for the old generation than for the young generation. Similarly, in the } \\
\text { baseline model, cost decreases the utility of the old generation more than the utility of the } \\
\text { young generation. This result is however inversed once we include the "current situation" } \\
\text { variable, furthermore the estimated coefficient of the cost attribute is no longer } \\
\text { significant for the old generation. This latter result is in contradiction with the theoretical } \\
\text { priors as we would have expected retirees to be in favour of a higher contribution rate as } \\
\text { they don't contribute to the system anymore and are net beneficiaries. Finally, the } \\
\text { estimated coefficient for the variable "current system" is negative but not significant for } \\
\text { the old generation. It is negative and significant at the } 1 \% \text { level for the young generation } \\
\text { suggesting that the younger prefer departing from the current state pension scheme. }\end{array}$} \\
\hline
\end{tabular}


Maintaining the current pension system decreases the utility of the old generation less than the utility of the young generation. However, from theoretical findings, we would expect the current pension system alternative to have a positive effect on the utility of the pensioners and they gain from this system.

\subsubsection{Testing for Age and Income Heterogeneity in Evaluating the Public Pension System}

Table 11 reports the estimation results for four separate groups: old and low income, old and high income, young and low income and young and high income agents.

The estimated coefficients for the high income-old generation are all of the expected sign, but only three variables: the high pension benefit, its squared value and the cost are significant at the 1\% level. Poverty rate is significant at the 5\% level. The estimated coefficients for the low income-old generation are also all of the expected sign, apart from the retirement age which is positive. The low pension benefit and its squared value are significant at the $1 \%$ level. The high pension benefit and its squared value are significant at the 5\% level. All the other estimates are not significant. The estimated coefficients for the high income-young generation are of the expected sign. However poverty rate, its squared value and the retirement age are not significant. Finally, the estimated coefficients for the low income-young generation are all of the expected sign apart from the retirement age which is positive. All the variables are significant apart from the squared value of poverty, the squared value of cost and the retirement age.

The estimated coefficient of the low pension benefit is the lowest for the low incomeyoung generation which is surprising as we expect it to be the lowest for the high incomeyoung generation. However, it is the highest for the low income-old generation, which is as expected. The estimated coefficient for the high pension benefit is also the lowest for the low-income-young group. Poverty aversion is the highest among the high income-old generation, followed by the low income-young generation, suggesting that poverty aversion is still a crucial element in the evaluation of the pension system. Poverty aversion is thus independent from age and income. Cost aversion is also the highest among the high income-old generation. This is also not expected. Indeed, the older should be the more in favour of increasing contribution rates to the public pension system as they are not any more in the tax system; similarly, we expect a higher contribution to decrease the utility of the low income individuals more than the utility of the high income individuals. 
Table 11

Estimation Results for Four Groups Differentiated by Age and Income

\begin{tabular}{|l|c|c|c|c|}
\hline Variable & $\begin{array}{c}\text { over 65 years \& } \\
\text { above me dian income }\end{array}$ & $\begin{array}{c}\text { over 65 years \& } \\
\text { below median income }\end{array}$ & $\begin{array}{c}\text { Below 65 years \& } \\
\text { above median income }\end{array}$ & $\begin{array}{c}\text { Below 65 years \& } \\
\text { below median income }\end{array}$ \\
\hline State pension benefit for & 0.138 & 0.242 & 0.132 & 0.126 \\
\hline a low income individual & $(1.85)$ & $(2.73)^{* *}$ & $(4.07)^{* *}$ & -0.0002 \\
\hline Low pension-squared & -0.0002 & -0.0005 & -0.0002 & $(-3.67)^{* *}$ \\
\hline & $(-1.80)$ & $(-2.62)^{* *}$ & $(-3.79)^{* *}$ & 0.010 \\
\hline State pension benefit for & 0.023 & 0.019 & 0.011 & $(2.84)^{* *}$ \\
\hline a high income individual & $(3.14)^{* *}$ & $(2.20)^{*}$ & $(3.44)^{* *}$ & -0.00001 \\
\hline High-pension-squared & -0.00002 & -0.00002 & -0.00001 & $(-3.86)^{* *}$ \\
\hline & $(-3.05)^{* *}$ & $(-2.45)^{*}$ & $(-4.67)^{* *}$ & -16.667 \\
\hline Poverty rate among & -22.741 & -6.006 & -4.098 & $(-3.65)^{* *}$ \\
\hline the elderly & $(-2.32)^{*}$ & $(-0.51)$ & $(-0.95)$ & 28.869 \\
\hline poverty-squared & 36.524 & -27.450 & -16.023 & $(1.62)$ \\
\hline Cost for an average & $(0.97)$ & $(-0.55)$ & $(-0.94)$ & -0.118 \\
\hline worker & -0.322 & -0.221 & -0.118 & $(-2.15)^{*}$ \\
\hline Cost-squared & $(-2.80)^{* *}$ & $(-1.54)$ & $(-2.25)^{*}$ & 0.001 \\
\hline & 0.002 & 0.001 & 0.001 & $(1.75)$ \\
\hline Retirement age & $(1.83)$ & $(1.05)$ & $(2.12)^{*}$ & 0.006 \\
\hline & -0.051 & 0.043 & -0.040 & $(0.26)$ \\
\hline log likelihood & $(-0.87)$ & $(0.66)$ & -1340.08 & -1180.32 \\
\hline & -262.91 & -212.40 & & \\
\hline Value of z statistics in parentheses $* *$ significant at 5\%;*significant at $1 \%$ & & & \\
\hline
\end{tabular}

\subsubsection{Testing for value orientation}

Apart from the two most commonly advanced reasons (age and income) to explain people's heterogeneity in evaluating pensions, people's utility may be affected differently because of value judgments about equality and social justice in general and regarding the objectives and principles of a pension system in particular.

Table 12 reports regression results introducing interactions between attitudinal characteristics of the respondents and choice specific attributes for the whole sample. The estimate coefficients for the choice specific attributes are all significant at the 1 percent level and of the expected sign. Almost all interactions are of the expected sign. Interactions displaying significant parameters at the 1 percent level suggest that people's attitudes regarding the role of the state in the income redistribution and their opinion about the principles of the pension system are important determinants in their evaluation of the state pension scheme. 
Table 12

Estimated Results for Attitudinal Interactions 
Variable

State pension benefit for a

low income individual

Low pension-squared

State pension benefit for a

high income individual

High-pension-squared

Poverty rate among the elderly

poverty-squared

Cost for an average worker

Cost-squared

Retirement age

Benefit for a high income individual*poverty

Poverty rate among the elderly*cost

Benefit for a low income individual*cost

Poverty rate*retirement age

Benfit for a high income individual*retirement age

People will have to work longer

*retirement age

The state will have to spend more on pensions*low pension

The state will have to spend more on pensions*high pension

People will have to work longer*cost

The state will have to spend more on pensions*cost

The state will have to spend more on pensions*poverty rate

Less inequality and more tax *low pension

More inequality and less tax

*high pension

Less inequality and

more tax*cost

Value of $z$ statistics in parentheses; $*$ significant at $5 \%$;* significant at $1 \%$
Total s ample

0.399 More inequality and less tax ${ }^{*} \cos t \quad-0.038$

$(8.17)^{* *}$

$(-2.06)^{*}$

-0.001 Less inequality and more tax 0.615

$(-7.30) * * *$ poverty rate

(0.32)

$\begin{array}{lll}0.021 & \text { Income difference in Ireland } & 0.0001\end{array}$

(1.78) are too large*low pension $\quad(0.06)$

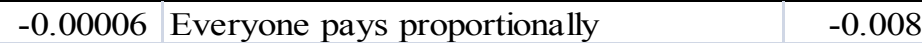

$(-5.09) * *$ the same*low pension

$(-2.10)^{*}$

-485.977 Everyone pays proportionally

0.001

$(-8.22)^{* *}$ the same*high pension

$(4.02) * *$

506.097 Everyone pays proportionally

1.573

$(6.74) * *$ the same*poverty rate

(0.86)

$\begin{array}{lll}-3.942 & \text { The poor receive a higher } & 0.017\end{array}$

$(-6.03)^{* *}$ pension benefit*low pension $(6.05)^{* *}$

0.008 The poor receive a higher -0.001

$(3.62)^{* *}$ pension benefit*high pension

$(-4.64) * *$

-0.216 Pensionproportional to earnings 0.0004

$(-3.71)^{* *}$ before retirement*high pension

-0.481 Everyone has the same -8.178

$(-6.57)^{* *}$ pension benefit*poverty rate $(-6.64) * *$

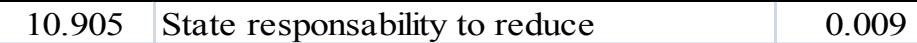

$(6.47) * *$ inequality*high pension

$(7.17)^{* *}$

0.011 State responsability to reduce -0.117

$(5.83) * *$ inequality*cost

$(-7.41)^{* *}$

1.276 Individual responsibility to save 0.001

$(2.65)^{* *}$ for its old age*high pension $\quad(2.95)^{* *}$

\begin{tabular}{l|l|l}
0.0004 & State responsibility to provide pensioners 0.014
\end{tabular}

$(3.21) * * \quad$ with a pension benefit*low pension

0.015

(0.39)

0.0008

(0.22)

0.005

$(2.40)^{*}$

$-0.014$

$(-2.91)^{* *}$

$-0.072$

$(-2.26)^{*}$

$-2.204$

(-0.76)

0.001

(0.47)

0.005

$(3.40)^{* *}$

0.016

(2.73)** Log likelihood

$-1887.24$

\section{Conclusion}


This paper has analyzed the different forces that can affect people's evaluation of the state pension system. Data used to estimate individuals' well-being come from a choice experiment conducted in Ireland in 2008. Respondents were presented with several choice sets, each containing four alternatives from which they had to choose one. Each alternative has different implications for the extent of intra-generational and intergenerational redistribution. In general, within the political economy literature about demand for redistribution though social security, it is assumed that individuals' utility is determined by their self-interest. In this respect, individuals' own characteristics as income and age play a significant role. Nevertheless, other forces, as altruism and social preferences, may also explain people's demand for redistribution. In this respect, estimation results have shown that poverty and inequality aversion indeed affect individuals' utility and their demand for redistribution. All individuals, regardless of age and income are poverty averse and a higher poverty among the elderly decreases utility at an important degree. When the evaluation of the levels of pension benefits depends on age and income of respondents, cost and poverty are independent.

Results induced by interactions between individual-specific characteristics and choicespecific attributes confirm how people's demand for redistribution through the state pension scheme is also driven by their perception of inequality, poverty, redistribution and their value orientation concerning pensions. Several other models not reported have also been estimated to test for heterogeneity in preferences. Notably, interacting political variables with the choice specific attributes has shown that the level of social contract as well as party partisanship partly explains individuals' heterogeneity in their preferences for different kinds of state pension systems.

One next objective of the study is to derive implicit prices for the pension-specific selected attributes and to investigate individuals' preferences heterogeneity in Willingness to Pay (WTP) for pension reforms. Individual preferences will be aggregated through a majority voting mechanism that handles multidimensional policy issue space (probabilistic voting model) in order to determine pension policy that will be implemented at the national level. Finally, it will be interesting to use the aggregated data from the choice experiment within a micro-simulation framework to account for the impact population ageing on the shape of the public pension system. 


\section{Appendix}

Appendix 1 : Example of a choice set

\begin{tabular}{|c|c|c|c|c|}
\hline Features of the State pension system Policy option & $\begin{array}{l}\text { Current } \\
\text { situation }\end{array}$ & $\begin{array}{l}\text { Policy } \\
\text { option A }\end{array}$ & $\begin{array}{l}\text { Policy } \\
\text { option B }\end{array}$ & $\begin{array}{l}\text { Policy } \\
\text { option C }\end{array}$ \\
\hline $\begin{array}{l}\text { 1. Weekly State Pension for a low income } \\
\text { individual }\end{array}$ & $\leq € 210$ & $€ 210$ & $€ 180$ & $€ 220$ \\
\hline $\begin{array}{l}\text { 2. Weekly State Pension for a high income } \\
\text { individual }\end{array}$ & $\leq € 210$ & $€ 210$ & $€ 180$ & $€ 0$ \\
\hline $\begin{array}{l}\text { 3. Weekly contribution to finance State pensions } \\
\text { for the average wage }\end{array}$ & $€ 30-€ 35$ & $€ 35-€ 40$ & $€ 30-€ 35$ & $€ 15-€ 20$ \\
\hline 4. Poverty rate among the elderly. & $\begin{array}{l}\text { Medium } \\
(10 \%- \\
15 \%)\end{array}$ & $\begin{array}{c}\text { Low } \\
(5 \%-10 \%)\end{array}$ & $\begin{array}{l}\text { Medium } \\
(10 \%- \\
15 \%)\end{array}$ & $\begin{array}{l}\text { Medium } \\
(10 \%- \\
15 \%)\end{array}$ \\
\hline 5. Minimum retirement age & 65 & 65 & 65 & 68 \\
\hline Please Tick your preferred option & $\square$ & 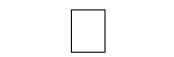 & $\square$ & $\square$ \\
\hline
\end{tabular}




\section{References}

Ageing and Employment Policies: Ireland, (2005), OECD.

Aging in OECD countries: A critical Policy Challenge, (1996), OECD Social Policy Studies, 20.

Ben-Akiva, M., and Lerman, S. (1985), Discrete Choice Analysis: Theory and Application to Travel Demand, MIT Press, Cambridge, MA.

Blamey, R., Gordon, J., and Chapman, R. (1999), Choice Modelling: Assessing the Environmental Values of Water Supply option, The Australian Journal of Agricultural and Resource Economics, 43(3), 337-357.

Boeri, T., Börsch-Supan, A., and Tabellini, G. (2001), Would You Like to Shrink the Welfare State? A Survey of European Citizens, Economic Policy, 16(32), 7-50.

Bowles, S. and Herbert, G. (2000), Reciprocity, Self-Interest, and the Welfare State, Nordic Journal of Political Economy, 26 (1),

Browning, Edgar K. (1975), Why the Social Insurance Budget Is Too Large in a Democracy, Economic Inquiry. 13(3), 373-88.

Carson, Richard T. et al. (1994), Experimental Analysis of Choice, Marketing Letters, 5(4), 351-368.

Corneo, G., and Grüner, H. P. (2002), Individual preferences for political redistribution, Journal of Public Economics, 83, 83-107.

Delaney, L. and O'Toole, F. (2006), Preferences for Specific Social Welfare Expenditures in Ireland, UCD Geary Institute Discussion Paper Series, GEARY WP/8/2006.

Department of Social and Family Affairs, (2002), Sustainable and Adequate Pension Provision for an Ageing Population: Ireland's National Strategy Report to the EU Commission on its Pension System. Brussels: European Commission.

Department of Social and Family Affairs, (2007). Green Paper on Pensions, Dublin.

Devroye, D. (2003), Who Wants to Privatize Social Security? Understanding Why the Poor are Wary of Private Accounts, Public Administration Review, 63(3), 316-328.

DOF, (1998). Long Term Issues Group, Paper. Dublin: Department of Finance.

Eline C.M. van der Heijden", Jan H.M. Nelissenb, andHarrie A.A. Verbona, (1997), Altruism and fairness in a public pension system, Journal of Economic Behavior \& Organization, 32, 505-518

Esping-Andersen, G. (1985), Politics against Markets: The Social Democratic Road to Power. Princeton: Princeton University Press.

Ferrera, M. (1993), Citizens and Social Protection: Main Results from a Eurobarometer Survey, Brussels, EC.

Fong, C. (2001), Social Preferences, Self-Interest, and the Demand for Redistribution, Journal of Public Economics, 82, 225-246.

Gerald, J. F. (2004), Ireland - an Ageing Multicultural Economy, The Economic and Social Research Institute, Paper to Merriman Summer School.

Hall, J., Viney, R., Haas, M. and Louviere, J. (2004), Using stated preference discrete choice modeling to evaluate health care programs, Journal of Business Research 57, 1026- 1032.

Hamil-Luker, J. (2001), The prospects of Age War: Inequality between (and within) Age Groups, Social Science Research, 30, 386-400.

Hanley, N., Robert, E. W. and Gary, K. (2002), Modelling Recreation Demand Using Choice Experiments: Climbing in Scotland, Environmental and Resource Economics, 22, 449-466.

Hausman, J. and McFadden, D.L. (1984), Specification tests for the multinomial logit model, Econometrica, 52, 1219-1240.

Hensher, D.A. (1994), Stated preference analysis of travel choices: the state of practice, Transportation, 21, 107-133.

Hughes, G. and Whelan, B. (1996). Occupational and Personal Pension Coverage 1995, Dublin: ESRI.

Kenworthy, L. and McCall, L. (2008), Inequality, public opinion and redistribution, Socio-Economic Review, 6, 35-68.

Lancaster, K. (1966), A new approach to consumer theory, Journal of Political Economy, 74, 132-157.

Louviere, J. and Hensher, D. (1982), On the design and analysis of simulated choice or allocation experiments in travel choice modeling, Transportation Research Record 890, 11-17. 
Louviere, J.J. and Woodworth, G. (1983), Design and analysis of simulated consumer choice or allocation experiments: an approach based on aggregate data, Journal of Marketing Research, 20, 350-367.

Louviere, J.J. (1994), Conjoint Analysis. In R. Bagozzi (Ed.) Advances in Marketing Research. Cambridge, MA:Blackwell Publishers.

Luce, R.D. (1959), Individual Choice Behavior: A Theoretical Analysis. New York: John Wiley \& Sons.

Lynch, J. (2006), Pension Inequality and Pension Policy Preferences in Europe: Self-Interest, Policy Feedbacks, or None of the Above? Paper prepared for the 16th Conference of the Council of European Studies, Chicago.

Mazzanti, M. (2003) Discrete choice models and valuation experiments. Journal of Economic Studies, 30, 584-604.

McFadden, D. (1974), Conditional logit analysis of qualitative choice behavior, In: Zarembka, P. (Ed.), Frontiers in Econometrics. Academic Press, New York, 105-142.

McFadden, D. (1978) Modelling the choice of residential location. Spatial Interaction Theory and Residential Location (Karlquist A. Ed., pp. 75-96). North Holland, Amsterdam.

Meltzer, Allan H. and Richard, Scott F. (1981), A Rational Theory of the Size of Government," Journal of Political Economy, 89, 914-27.

Moene, K. O. and Wallerstein, M. (2003), Earnings Inequality and Welfare Spending, World Politics, 55, 485-516.

Morrison, M., Bennett, J., Blamey, R. and Louviere, J. (2002), Choice Modeling and Tests of Benefit Transfer, American Journal of Agricultural Econonomics, 84(1), 161-170.

Natali, D. (2004), Ireland: The Pension System, European Social Observatory Research Project.

National Pensions Board, (1993), Final Report: Developing the National Pensions System, The Stationary Office. Dublin.

National Pensions Board, (2008), National report and Accounts 2008.

National Pensions Board, (2005), National Pensions Review Report by the Pensions Board to Seamus Brennan TD, Minister for Social and Family Affairs, Dublin.

O'Donoghue, C. (2002), Redistributive Forces of the Irish Tax-Benefit System, Journal of the Statistical and Social Inquiry Society of Ireland, XXXII.

Pierson, P. (1994), Dismantling the Welfare State? Reagan, Thatcher, and the Politics of Retrenchment, Cambridge: Cambridge University Press.

Schwarze, J. and Häpfer, M. (2007), Are People Inequality Averse, and Do They Prefer Redistribution by the State? Evidence from German Longitudinal Data on Life Satisfaction, The Journal of Socio Economics, 36, 233-249.

Tabellini, G. (2000), A positive theory of social security, Skandinavian Journal of Economics, 102 (3), 523545.

The Pensions Board, (2006), Special Savings for Retirement. The Pensions Board, Dublin 2

Thurstone, L. (1927), A law of comparative judgment. Psychological Review 34, 273-286.

Train, K.E. (1998), Recreation demand models with taste differences across people, Land Economics 74 (2), 230-235.

Van Els, P.J.A, van den End, W.A. and van Rooij, M.C.J. (2003), Pensions and Public Opinion: a Survey Among Dutch Households, Research Memorandum WO No 752/Meb-Series N 2003-18.

van Groezen, B., Kiiver, H. and Unger, B. (2009), Explaining Europeans' preferences for pension provision, European Journal of Political Economy, 25(2), 237-246. 